\title{
HUBUNGAN ANTARA DUKUNGAN SOSIAL TERHADAP KECEMASAN AKADEMIK PADA MAHASISWA YANG MENYUSUN SKRIPSI DI MASA PANDEMI COVID-19 SEMESTER GENAP TAHUN AJARAN 2019/2020
}

\author{
THE RELATIONSHIP BETWEEN SOCIAL SUPPORT TOWARD ACADEMIC ANXIETY IN \\ STUDENTS WHO COMPLETE THESIS DURING THE COVID-19 PANDEMIC EVEN \\ SEMESTER OF THE 2019/2020 ACADEMIC YEAR
}

\author{
Oleh: \\ Winda Lestari ${ }^{1}$ \\ Dyah Astorini Wulandari ${ }^{2}$
}

\begin{abstract}
This study aims to determine the correlation between social support and academic anxiety in students compiling their thesis during the COVID-19 Pandemic Period in Even Semester Academic Year 2019/2020. Probability sampling with simple random sampling was used as the sampling technique in this study. The research subjects were 100 students. This research is a quantitative study with a validity test of the product-moment correlation technique. Academic Anxiety scale test shows a moving validity from 0.233 to 0.534 with 43 valid items with a reliability of 0.886. On the Social Support scale, it has a moving validity from 0.211 to 0.554 with 45 valid items. Based on the results of the Product Moment correlation hypothesis test, it shows a correlation value of -0.600 with $p$ of 0.000 (p0.01) on the scale of social support and academic anxiety scale. It can be concluded that the hypothesis stating there is acorrelation between social support and academic anxiety is accepted.
\end{abstract}

Keywords: Academic Anxiety, Final-year Student, Social Support

Penelitian ini bertujuan untuk mengetahui Hubungan antara Dukungan Sosial terhadap Kecemasan Akademik Pada Mahasiswa Yang Menyusun Skripsi Di Masa Pandemi COVID-19 Semester Genap Tahun Ajaran 2019/2020. Teknik pengambilan sampel dalam penelitian ini adalah menggunakan probability sampling dengan simple random sampling. Subjek penelitian yang digunakan sebanyak 100 mahasiswa. Penelitian ini merupakan penelitian kuantitatif dengan uji validitas menggunakan teknik korelasi product moment. Hasil uji analisis skala Kecemasan Akademik memiliki validitas bergerak dari 0,233 sampai 0,534 dengan 43 butir aitem yang valid dan mendapatkan reliabilitas sebesar 0,886. Pada skala Dukungan Sosial memiliki validitas bergerak dari 0,211 sampai 0,554 dengan 45 butir aitem yang valid. Berdasarkan hasil uji hipotesis korelasi Product Moment, dapat dijelaskan bahwa pada skala dukungan sosial dan skala kecemasan akademik menunjukkan nilai korelasi -0,600 dengan $p$ sebesar $0,000(\mathrm{p}<0,01)$. Maka dapat disimpulkan bahwa hipotesis yang menyatakan adanya hubungan antara dukungan sosial terhadap kecemasan akademik diterima.

Kata kunci : Dukungan Sosial, Kecemasan Akademik, Mahasiswa Akhir

\section{PENDAHULUAN}

Mahasiswa merupakan peserta didik yang terdaftar atau sedang menuntut ilmu dalam suatu perguruan tinggi. Mahasiswa merupakan seorang yang sedang belajar, menggunakan akal pikiran secara lebih aktif dan cermat, serta penuh perhatian untuk memahami suatu ilmu pengetahuan (Ramadhani, 2016). Pada dasarnya mahasiswa diharapkan mampu membangun bangsa dan negara menjadi lebih baik setelah menyelesaikan studinya dan menjadi seorang tenaga profesional sesuai dengan bidangnya masing-masing.

\footnotetext{
1 Winda Lestari, Fakultas Psikologi, Email: lestariwinda066@gmail.com

2 Dyah Astorini Wulandari, Fakultas Psikologi, Email: rinirifqi@gmail.com
} 
Mahasiswa dalam penyusunan skripsi sebagian mahasiswa mengalami hambatan dan kesulitan baik dari faktor internal maupun dari faktor eksternal. Faktor internal yaitu faktor dari dalam diri mahasiswa yang bersangkutan seperti, tidak mempunyai kemampuan dalam tulis menulis, kurangnya kemampuan akademis yang memadai, kurangnya ketertarikan mahasiswa dalam penelitian, tidak terbiasa menulis karya ilmiah dan kurang terbiasa dengan sistem kerja terjadwal dengan pengaturan waktu terbatas (Suseno, 2010).

Adapun faktor eksternal yaitu faktor yang berasal dari luar diri mahasiswa seperti kesulitan mencari literatur, dana yang terbatas, dan masalah dengan dosen pembimbing skripsi. Hal ini menyebabkan banyak mahasiswa yang seharusnya telah wisuda lebih awal menjadi terhambat dan membutuhkan waktu lebih lama untuk menyelesaikan skripsinya dan bahkan tidak sedikit yang gagal dalam menyelesaikan skripsi ini (Suseno, 2010).

Mahasiswa tingkat akhir merasa kesulitan mengerjakan tugas akhir atau skripsi karena pandemi Covid 19 di Indonesia. Beberapa kesulitannya adalah bimbingan secara online tidak terlaksana dengan baik karena tidak dapat memenuhi rasa ingin tahu mahasiswa terkait dengan skripsinya, sulit menjalankan penelitian langsung di lapangan.

Dikutip dari Tirto.id (2020), di tengah pandemi Covid 19 skripsi dapat mengakibatkan stres dan menjadi masalah utama yang paling dirasakan oleh mahasiswa. Skripsi dapat menimbulkan ketegangan psikis yang memburuk dan memunculkan kesehatan mental, kondisi emosional, kognisi, fisik, dan fungsi intrapersonal menentukan kondisi psikis mahasiswa pada saat mengerjakan skripsi. Dampak Covid 19 pada mahasiswa yang menyusun skripsi mengalami rasa cemas, mahasiswa mendapatkan kendala seperti wawancara secara langsung dan observasi yang seharusnya terjun ke lapangan.

Dikutip dari Kompas.com (2020) Corona virus disease 2019 atau disingkat Covid 19 adalah penyakit menular yang disebabkan oleh SARS-Cov-2, salah satu jenis coronavirus. Penderita Covid 19 akan mengalami demam, batuk kering, dan kesulitan bernafas. Pada penderita yang paling rentan penyakit ini dapat berujung pada pneumonia dan kegagalan multiorgan. Infeksi ini menyebar melalui percikan (droplet) dari saluran pernafasan yang sering dihasilkan saat batuk, atau bersin. Sampai saat ini belum ada vaksin atau obat yang dapat menyembuhkan penyakit ini. Pencegahan yang dapat dilakukan yaitu dengan rajin mencuci tangan, etika batuk, menghindari kontak jarak dekat dengan orang sakit.

Dikutip dari IDN Times (2020) Covid 19 di Indonesia ini berdampak pada banyak bidang termasuk pendidikan, sehingga pemerintah pusat hingga daerah memberi kebijakan untuk meliburkan lembaga pendidikan. Hal ini dilakukan untuk pemutus mata rantai virus, sehingga perguruan tinggi menerapkan kuliah online. Akibatnya mahasiswa tingkat akhir mengerjakan tugas akhir atau skripsi dengan bimbingan online. Mahasiswa merasakan kurang efektifnya bimbingan online, terhambat dalam pengambilan data ke lapangan, sehingga muncul kecemasan pada mahasiswa.

Mahasiswa tingkat akhir yang sedang mengerjakan tugas akhir atau skripsi mengalami kecemasan. Kecemasan pada bidang akademik seperti kesulitan dalam memahami suatu mata kuliah, tekanan mahasiswa dalam menghadapi ujian dan praktik. Kecemasan non akademik seperti hubungan dengan teman, dosen, finansial, hubungan dengan keluarga, dan lainnya. Kecemasan akademik adalah masalah penting yang akan memengaruhi sejumlah besar mahasiswa (Otten, 1991).

Kecemasan yang berlebihan akan berpengaruh secara negatif karena mahasiswa mengalami tekanan psikologi, penurunan perhatian dan konsentrasi sehingga mendapatkan hasil belajar yang kurang baik (Maddox, 2011). Kecemasan akademik adalah hasil dari proses dalam tubuh dan otak yang membutuhkan perhatian, seperti menyelesaikan tugas atau menghadapi ujian. Semua hal yang berhubungan dengan situasi pendidikan di perguruan tinggi dapat menimbulkan kecemasan akademik (Amanda \& Nugrahaeni, 2019). Kecemasan yang tinggi dapat juga menimbulkan gangguan fungsi sosial individu, misalnya perasaan cemas yang 
melanda mahasiswa dapat membuat mahasiswa tersebut kurang dapat mengaktualisasikan potensi dirinya (Nugroho, 2011).

Dikutip dari Untung Wahyudi (2020), mahasiswa yang merasakan kecemasan dalam mengerjakan tugas akhir akibat Covid 19 menjadi kurang bersemangat mengerjakan skripsi karena terhambat dalam pengambilan data di lapangan. Bimbingan online yang di laksanakan kurang efektif sehingga mahasiswa kurang progres dalam mengerjakan skripsi. Harapan yang besar pada keberhasilan mahasiswa untuk menyelesaikan penyusunan skripsi dan tuntutan untuk sesuai dengan kriteria yang ditetapkan lembaga pendidikan. Keadaan seperti ini mahasiswa membutuhkan adanya dukungan sosial dari berbagai pihak misalnya orang tua, karena kondisi pandemi Covid 19 dapat memicu ketegangan dan kecemasan.

Adanya pandemi Covid 19 ini salah satu termasuk faktor eksternal yang menghambat mahasiswa dalam menyelesaikan skripsi. Mahasiswa yang mengalami kecemasan akan cenderung minder, gugup, takut, bahkan ketika kecemasan dirasakan secara mendalam akan membuat mahasiswa tertekan. Faktor yang mempengaruhi kecemasan salah satunya adalah kurangnya dukungan sosial. Sedangkan manfaat dukungan sosial adalah mengurangi kecemasan, depresi dan simptom-simptom bagi tubuh mengalami stres.

Dukungan sosial adalah transaksi interpersonal yang meliputi perasaan emosional seperti perasaan suka, cinta dan empati (House \& Khan, 1985). Dukungan sosial sangat penting untuk dipahami karena dukungan sosial menjadi sangat berharga ketika individu mengalami suatu masalah oleh karena itu individu yang bersangkutan membutuhkan orang-orang terdekat yang dapat dipercaya untuk membantu dalam mengatasi permasalahannya tersebut.

Oleh karena itu, dukungan sosial sangat penting dalam hal untuk mereduksi kecemasan yang ada dalam individu. Termasuk ketika menyelesaikan skripsi mahasiswa membutuhkan dukungan sosial, seperti bantuan dari keluarga, ataupun teman. Hal tersebut dikarenakan dukungan sosial dapat mengurangi kecemasan pada mahasiswa tingkat akhir, khususnya ketika menyelesaikan tugas akhir.

Adapun penelitian ini bertujuan untuk mengetahui hubungan antara dukungan sosial terhadap kecemasan akademik pada mahasiswa yang menyusun skripsi di masa pandemi COVID-19 semester genap tahun ajaran 2019/2020. Hal ini yang membuat peneliti tertarik untuk meneliti "hubungan antara dukungan sosial terhadap kecemasan akademik pada mahasiswa yang menyusun skripsi di masa pandemi COVID-19 semester genap tahun ajaran 2019/2020”.

\section{METODE PENELITIAN}

\section{Identifikasi Variabel}

1. Variabel Terikat (Y) : Kecemasan Akademik

2. Variabel Bebas $(\mathrm{X})$ : Dukungan Sosial

\section{Subjek Penelitian}

Populasi dalam penelitian ini adalah Mahasiswa yang menyusun skripsi prodi psikologi dan teknik informatika Universitas Muhammadiyah Purwokerto yang berjumlah 286 orang dengan masing-masing 155 orang prodi psikologi dan 131 orang prodi teknik informatika. Sampel penelitian ini berjumlah 100 mahasiswa.

\section{Alat Pengumpulan Data}

Dalam penelitian ini, pengumpulan data menggunakan angket yang berbentuk skala likert yaitu skala kecemasan akademik dan skala dukungan sosial. Skala kecemasan akademik disusun sendiri oleh peneliti berdasarkan 3 aspek yaitu reaksi kognitif, kognitif dan psikologis. Skala dukungan sosial disusun sendiri oleh peneliti berdasarkan 5 aspek yaitu emosi, penghargaan, instrumental, informasi, dan jaringan sosial. Skala kecemasan akademik dan skala dukungan sosial terdiri dari 50 aitem dengan bentuk pernyataan bersifat tertutup, artinya subjek 
hanya memilih satu di antara 5 alternatif jawaban yang telah disediakan dengan memberi tanda centang. Dalam menjawab aitem favorabel, subjek memperoleh skor 5 apabila memilih jawaban SS (Sangat Setuju), skor 4 apabila memilih jawaban S (Setuju), skor 3 apabila memilih jawaban N (Netral), skor 2 apabila memilih jawaban TS (Tidak Setuju), dan skor 1 apabila memilih jawaban STS (Sangat Tidak Setuju). Sementara dalam menjawab aitem unfavorabel, subjek akan mendapatkan skor 1 apabila memilih jawaban SS (Sangat Setuju), skor 2 apabila memilih jawaban S (Setuju), skor 3 apabila memilih jawaban N (Netral), skor 4 apabila memilih jawaban TS (Tidak Setuju), dan skor 5 apabila memilih jawaban STS (Sangat Tidak Setuju).

Berdasarkan perhitungan validitas skala Kecemasan Akademik memiliki validitas bergerak dari 0,233 sampai 0,534 dengan 43 butir aitem yang valid dan mendapatkan reliabilitas sebesar 0,886. Pada skala Dukungan Sosial memiliki validitas bergerak dari 0,211 sampai 0,554 dengan 45 butir aitem yang valid dan mendapatkan reliabilitas sebesar 0,872 dengan taraf signifikansi 5\% dengan $\mathrm{R}_{\text {tabel }}=0,195$. Berdasarkan hasil uji hipotesis korelasi Product Moment, dapat dijelaskan bahwa pada skala dukungan sosial dan skala kecemasan akademik menunjukkan nilai korelasi -0,600 dengan p sebesar 0,000 ( $<<0,01)$.

\section{Analisis Data}

Analisis data yang digunakan pada penelitian ini adalah analisis product moment

\section{HASIL DAN PEMBAHASAN}

Hubungan antara dukungan sosial terhadap kecemasan Akademik pada mahasiswa tahun ajaran 2019/2020 (semester genap) yang menyusun skripsi semester akibat dampak COVID-19. Berdasarkan pada hasil regresi sederhana, diperoleh persamaan garis regresi yaitu $Y=38,287$ - 0,691 X. Dapat disimpulkan bahwa setiap peningkatan satu satuan dukungan sosial akan menurunkan kecemasan akademik sebesar 0,691. Berdasarkan analisis regresi diperoleh nilai $F_{\text {hitung }}=55,083$ dengan nilai probabilitas sig $(\mathrm{p})=0,000(\mathrm{p}<0,01)$. Dengan demikian maka hipotesis yang menyatakan ada hubungan dukungan sosial terhadap kecemasan akademik diterima.

Berdasarkan hasil uji hipotesis korelasi Product Moment, dapat dijelaskan bahwa pada skala dukungan sosial dan skala kecemasan akademik menunjukkan nilai korelasi -0,600 dengan $\mathrm{p}$ sebesar $0,000(\mathrm{p}<0,01)$. Sumbangan efektif dukungan sosial terhadap kecemasan akademik sebesar $60 \%$, artinya semakin tinggi dukungan sosial maka semakin rendah kecemasan akademik pada mahasiswa yang menyusun skripsi. Maka dapat disimpulkan bahwa hipotesis yang menyatakan adanya hubungan antara dukungan sosial terhadap kecemasan akademik diterima.

Hasil penelitian ini dapat diketahui bahwa persentase pada tiap karakteristik responden yaitu 3\% (3 orang) memiliki kecemasan akademik yang sangat tinggi, 15\% (15 orang) memiliki kecemasan akademik yang tinggi, 65\% (65 orang) memiliki kecemasan akademik yang sedang, 17\% (17orang) memiliki kecemasan akademik yang rendah dan $0 \%$ tidak ada yang memiliki kecemasan akademik yang sangat rendah. Namun, mayoritas mahasiswa berada pada kategori kecemasan akademik sedang dengan persentase 65\% dengan jumlah sebanyak 65 mahasiswa. Sedangkan persentase data statistik diperoleh skor dukungan sosial menunjukkan $4 \%$ (4 orang) memiliki dukungan sosial yang sangat tinggi, 11\% (11 orang) memiliki dukungan sosial yang tinggi, 32\% (32 orang) memiliki dukungan sosial yang sedang, 16\% (16 orang) memiliki dukungan sosial yang rendah dan $1 \%$ (1 orang) memiliki dukungan sosial yang sangat rendah. Mayoritas mahasiswa juga berada pada kategori dukungan sosial sedang dengan persentase $32 \%$ dengan jumlah sebanyak 32 mahasiswa.

Kemudian, berdasarkan hasil dari penelitian dapat diketahui bahwa penelitian ini sejalan dengan penelitian sebelumnya dengan hipotesis yang menyatakan ada hubungan 
dukungan sosial terhadap kecemasan akademik diterima. Dari perhitungan hipotesis korelasi Product Moment, dapat dijelaskan bahwa pada skala dukungan sosial dan skala kecemasan akademik menunjukkan nilai korelasi $-0,600$ dengan $p$ sebesar $0,000(p<0,01)$. Sumbangan efektif dukungan sosial terhadap kecemasan akademik sebesar $60 \%$, artinya semakin tinggi dukungan sosial maka semakin rendah kecemasan akademik pada mahasiswa yang menyusun skripsi.

Hasil penelitian ini sejalan dengan penelitian sebelumnya yang menyatakan bahwa ditemukan seluruh aspek pada dukungan sosial teman sebaya memiliki pengaruh yang signifikan dengan kecemasan akademik $(\mathrm{p}<0.05)$. Selain itu ditemukan pula aspek penghargaan pada variabel dukungan sosial teman sebaya memiliki pengaruh yang paling besar dibandingkan dengan aspek-aspek dukungan sosial teman sebaya yang lain dengan nilai $\mathrm{r}=-0,476$ dan nilai sumbangsih sebesar 22,6\%. Hal ini ditunjukkan dari nilai koefisien korelasi (r) sebesar $-0,422$ dengan $\mathrm{p}=0,00$. Sumbangan efektif dukungan sosial teman sebaya terhadap kecemasan akademik sebesar $42,7 \%$. Artinya, semakin tinggi dukungan sosial teman sebaya yang diberikan maka semakin rendah kecemasan akademik yang dimiliki responden (Anggoro, 2018).

Penelitian ini juga searah dengan penelitian lain yang dilakukan oleh (Sutikno, 2015). dengan judul hubungan antara dukungan sosial teman dengan kecemasan akademik pada mahasiswa. Berdasarkan analisis data diperoleh nilai korelasi sebesar $-0,530$ dengan $\mathrm{p}=0,000$ $(\mathrm{p}<0,01)$, artinya ada hubungan negatif yang sangat signifikan antara dukungan sosial teman dengan kecemasan akademik. Semakin tinggi dukungan sosial teman maka semakin rendah kecemasan akademik, demikian juga sebaliknya.

Kecemasan adalah reaksi normal yang ditunjukkan oleh seseorang terhadap stresor yang muncul untuk membantu individu menghadapi situasi yang menuntut motivasi individu dalam mengatasinya, tetapi ketika kecemasan menjadi berlebihan hal ini dapat memiliki dampak serius pada kehidupan sehari-hari dan mengganggu fungsi normal seseorang (Hartley \& Phelps, dalam Singh \& Jha, 2013). Motivasi untuk menghadapi kecemasan ini bisa muncul dari dukungan sosial yang diberikan oleh individu lainnya, seperti yang dijelaskan bahwa dukungan sosial dapat melindungi individu dari gangguan kesehatan mental, seperti depresi. Pada dasarnya, individu yang memiliki dukungan sosial teman sebaya yang tinggi dilatar belakangi oleh faktor dari dalam dan luar individu (Bozo, et al dalam Andarini \& Fatma, 2013).

Hasil penelitian ini dapat diketahui bahwa persentase pada tiap karakteristik responden yaitu 3\% (3 orang) memiliki kecemasan akademik yang sangat tinggi, 15\% (15 orang) memiliki kecemasan akademik yang tinggi, 65\% (65 orang) memiliki kecemasan akademik yang sedang, $17 \%$ (17orang) memiliki kecemasan akademik yang rendah dan $0 \%$ tidak ada yang memiliki kecemasan akademik yang sangat rendah. Namun, mayoritas mahasiswa berada pada kategori kecemasan akademik sedang dengan persentase 65\% dengan jumlah sebanyak 65 mahasiswa. Sedangkan persentase data statistik diperoleh skor dukungan sosial menunjukkan $4 \%$ (4 orang) memiliki dukungan sosial yang sangat tinggi, 11\% (11 orang) memiliki dukungan sosial yang tinggi, 32\% (32 orang) memiliki dukungan sosial yang sedang, 16\% (16 orang) memiliki dukungan sosial yang rendah dan $1 \%$ (1 orang) memiliki dukungan sosial yang sangat rendah. Mayoritas mahasiswa juga berada pada kategori dukungan sosial sedang dengan persentase $32 \%$ dengan jumlah sebanyak 32 mahasiswa.

Berdasarkan uraian distribusi frekuensi tersebut, dapat disimpulkan bahwa meningkatkan dukungan sosial mampu memiliki hubungan kecemasan akademik pada mahasiswa yang menyusun skripsi di masa pandemi COVID-19, sehingga semakin tinggi mahasiswa yang memiliki dukungan sosial dari lingkungan maka semakin rendah pula kecemasan akademik yang dimiliki mahasiswa.

\section{KESIMPULAN}

Berdasarkan hasil analisis dan pembahasan peneliti menyimpulkan bahwa bahwa ada hubungan antara dukungan sosial terhadap kecemasan akademik pada mahasiswa yang 
menyusun skripsi di masa pandemi COVID-19 semester genap tahun ajaran 2019/2020. Dengan demikian maka hipotesis yang menyatakan ada hubungan antara dukungan sosial terhadap kecemasan akademik pada mahasiswa yang menyusun skripsi di masa pandemi COVID-19 semester genap tahun ajaran 2019/2020 dapat diterima.

Hasil penelitian menunjukkan bahwa hubungan dukungan sosial terhadap kecemasan akademik menunjukkan arah yang negatif. Hal ini menunjukkan bahwa semakin tinggi dukungan sosial maka semakin menurunkan kecemasan akademik, begitu juga sebaliknya apabila semakin rendah dukungan sosial maka semakin tinggi kecemasan akademik.

\section{SARAN}

Peneliti memberikan beberapa saran sebagai bahan pertimbangan sebagai penyempurnaan penelitian selanjutnya, adapun saran dalam penelitian ini ditujukan bagi subjek peneliti, agar dapat meningkatkan dukungan sosial terhadap teman atau lingkungan sekitar agar menurunkan kecemasan akademik pada mahasiswa yang menyusun skripsi. Bagi peneliti selanjutnya yang tertarik untuk melakukan penelitian dengan variabel kecemasan akademik diharapkan untuk memperluas lingkup penelitian dan menghubungkan dengan variabel selain dukungan sosial dengan kecemasan akademik.

\section{DAFTAR PUSTAKA}

Andarini, S. R. \& Fatma, A. (2013). Hubungan antara Distres dan Dukungan Sosial dengan Prokrastinasi Akademik pada Mahasiswa dalam Menyusun Skripsi. Jurnal Talenta Psikologi, 2(2).

Anggoro, Kresna W. (2018). Hubungan Antara Dukungan Sosial Teman Sebaya Dengan Kecemasan Akademik Pada Mahasiswa Program Studi Akuntansi Universitas Islam Indonesia Menghadapi Ujian Komprehensif. UII. Skripsi.

Amanda, K., \& Nugrahaeni, P. (2019). Hubungan antara kecemasan akademik dan sleep paralysis pada mahasiswa Fakultas Kedokteran Universitas Udayana tahun pertama. Jurnal Psikologi Udayana, 6(1), 1-10.

House, J \& Khan, R.L. (1985). Measures and Concept of Social Support . London: Academic Press Inc.

Kompas.com (2020, 2 April). Wabah Corona Masa Studi Mahasiswa Tingkat Akhir yang Terancam DO Diperpanjang 1 Semester. Dikutip 27 Juni 2020 :https://edukasi.kompas.com/read/2020/04/02/192357771/wabah-masa-studi-mahasis wa-tingkat-akhir-yang-terancam-DO.

Nugroho, F. W. (2011). Hubungan Antara Hardiness Dengan Kecemasan. Jurnal Empati, 1-9.

Ottens, A.J. (1991). Coping with academic anxiety. New York: The Rosen Publishing Group.

Suseno, S. (2010). Pengaruh Dukungan Sosial dan Kepemimpinan Transformasional Terhadap Komitmen Organisasi dengan Mediator Motivasi Kerja. Jurnal Psikologi, 37(1), 94-109.

Sutikno, Yani M. (2015). Hubungan Antara Dukungan Sosial Teman Dengan Kecemasan Akademik Pada Mahasiswa. Universitas Katolik Soegijapranata Semarang. Skripsi.

Wahyudi Untung. (2020, 19 April). Nasib Pejuang Skripsi di Tengah Pandemi COVID-19. Dikutip $27 \quad$ Juni 2020

(https://www.viva.co.id/vstory/opini-vstory/1211575-nasib-pejuang-skripsi-di-tengah-pand emi-covid-19). 